\title{
Reversible giant arachnoid granulations
}

Guillaume Taieb, MD, Cyril Dargazanli, MD, Pauline Prin, MD, Mahmoud Charif, MD, and Anne Ducros, MD, PhD

Neurology ${ }^{\circledR}$ 2018;91:1107-1108. doi:10.1212/WNL.0000000000006656
Correspondence

Dr. Taieb

taiebguillaume@gmail.com

Figure CSF and blood compartment changes after depletive lumbar puncture

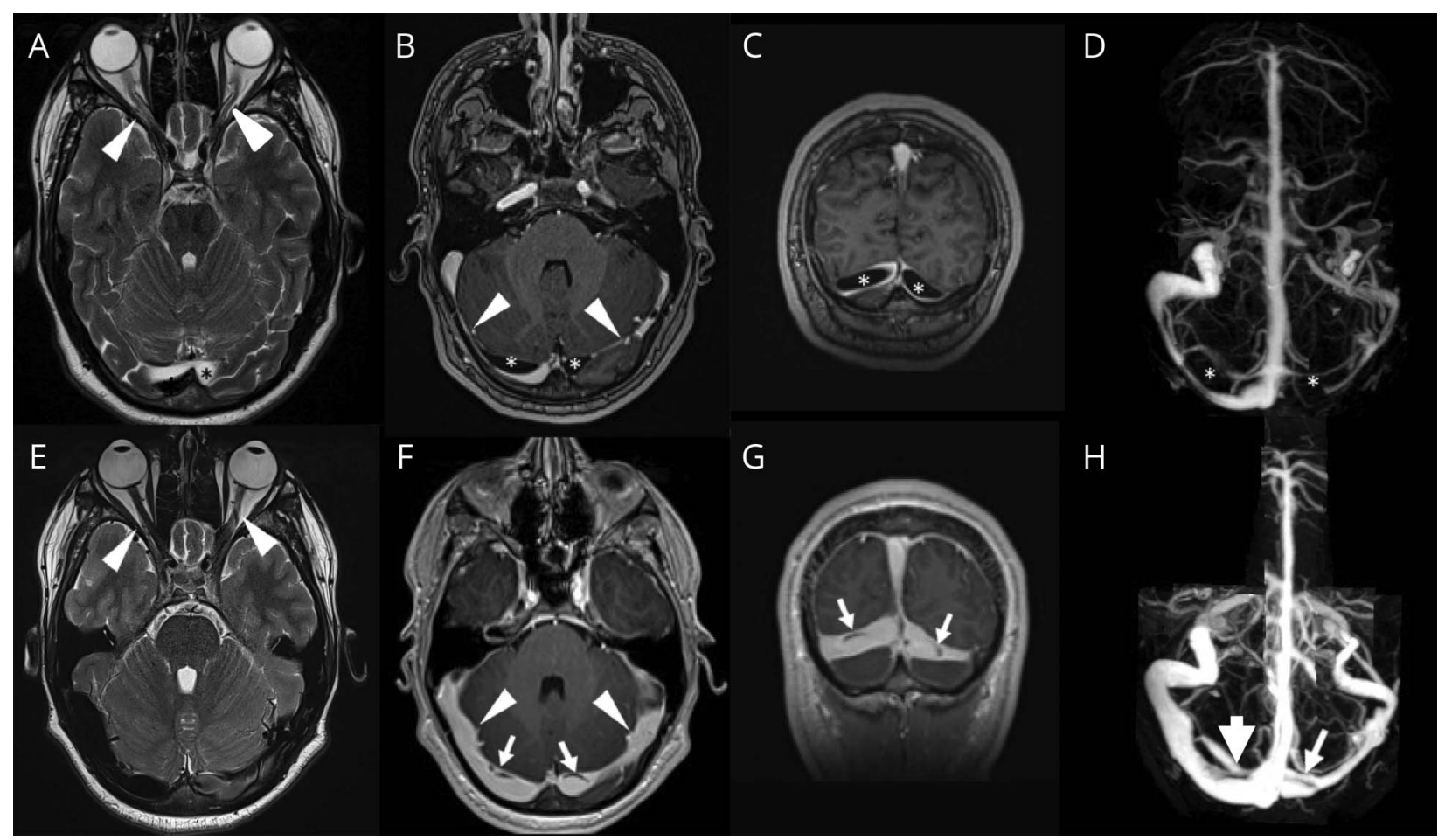

Axial T2-weighted image shows optic nerve tortuosities (arrowheads, A). Axial (B) and frontal (C) postcontrast T1-weighted imaging and magnetic resonance venography (D) reveal giant arachnoid granulations (GAG) (asterisks) and sinus lumen stenosis (arrows, B). Five days after lumbar puncture, optic nerve tortuosities (arrowheads, E), GAG (arrows, F-H), and sinus lumen stenosis (arrowheads, F) disappeared.

A 16-year-old boy with recurrent transient visual loss had bilateral papilledema. MRI revealed giant arachnoid granulations (GAG) in both transverse sinuses and signs of intracranial hypertension (figure). CSF opening pressure was $420 \mathrm{~mm} \mathrm{H}_{2} \mathrm{O}$. After depletive lumbar puncture, the size of GAG decreased and sinus lumen stenosis resolved (figure). Arachnoid granulations (AG) are CSF herniations through dural defects into sinuses. ${ }^{1}$ Since CSF removal led to their regression, GAG might be a consequence of intracranial hypertension. Our case supports the Krisch theory, which considers AG as a buffer of CSF compartment rather than a site of CSF absorption. ${ }^{2}$

\section{Author contributions}

G. Taieb: analysis and interpretation of data, drafting, critical revision of manuscript for intellectual content. C. Dargazanli: drafting and revision of manuscript, acquisition of data. P. Prin: acquisition of data, critical revision of manuscript for intellectual content. M. Charif: 
critical revision of manuscript for intellectual content. A. Ducros: analysis and interpretation of data, drafting, critical revision of manuscript for intellectual content.

\section{Study funding}

No targeted funding reported.

\section{Disclosure}

The authors report no disclosures relevant to the manuscript. Go to Neurology.org/N for full disclosures.

\section{References}

1. le Gros Clark WE. On the pacchionian bodies. J Anat 1920;55:40-48.

2. Krisch B. Ultrastructure of the meninges at the site of penetration of veins through the dura mater, with particular reference to pacchionian granulations. Investigations in the rat and two species of New-World monkeys (Cebus apella, Callitrix jacchus). Cell Tissue Res 1988;251:621-631.

\section{Did You Know...}

... you can browse by subspecialty topics on Neurology.org?

Go to: Neurology.org and click on "Topics" in the top navigation bar.

\section{Visit the Neurology ${ }^{\circledR}$ Website at Neurology.org/N}

- More article-based content on home pages

- Streamlined menus and navigation

- Enhanced blog sections for specialty areas

- Same experience on desktop, tablet, and mobile devices

- Audio summaries of current issues

- Improved article reading experience; links more evident (pdf, analytics, social media)

- Neurology ${ }^{\circledR}$ Clinical Practice initiative "Practice Current" global surveys will be accessible across sites

f Find Neurology ${ }^{\circledR}$ on Facebook: http://tinyurl.com/neurologyfan

Follow Neurology ${ }^{\circledR}$ on Twitter: https://twitter.com/GreenJournal

\section{Disputes \& Debates: Rapid online correspondence}

The editors encourage comments on recent articles through Disputes \& Debates:

Access an article at Neurology.org/ $\mathrm{N}$ and click on "COMMENT" beneath the article header. Responses will be posted within 3 business days.

Before submitting a comment to Disputes \& Debates, remember the following:

- Disputes \& Debates is restricted to comments about studies published in Neurology within the last eight weeks

- Read previously posted comments; redundant comments will not be posted

- Your submission must be 200 words or less and have a maximum of five references; reference one must be the article on which you are commenting

- You can include a maximum of five authors (including yourself) 


\title{
Neurology
}

\author{
Reversible giant arachnoid granulations \\ Guillaume Taieb, Cyril Dargazanli, Pauline Prin, et al. \\ Neurology 2018;91;1107-1108 \\ DOI 10.1212/WNL.0000000000006656
}

This information is current as of December 10, 2018

$\begin{array}{ll}\begin{array}{l}\text { Updated Information \& } \\ \text { Services }\end{array} & \begin{array}{l}\text { including high resolution figures, can be found at: } \\ \text { http://n.neurology.org/content/91/24/1107.full }\end{array} \\ \text { References } & \text { This article cites } 2 \text { articles, } 0 \text { of which you can access for free at: } \\ \text { http://n.neurology.org/content/91/24/1107.full\#ref-list-1 } & \text { This article, along with others on similar topics, appears in the } \\ \text { following collection(s): } \\ \text { Idiopathic intracranial hypertension } \\ \text { http://n.neurology.org/cgi/collection/idiopathic_intracranial_hypertensi } \\ \text { on } \\ \text { MRI } \\ \text { http://n.neurology.org/cgi/collection/mri } \\ \text { Information about reproducing this article in parts (figures,tables) or in } \\ \text { its entirety can be found online at: } \\ \text { http://www.neurology.org/about/about_the_journal\#permissions } \\ \text { Pnformation about ordering reprints can be found online: } \\ \text { Inttp://n.neurology.org/subscribers/advertise }\end{array}$

Neurology ${ }^{\circledR}$ is the official journal of the American Academy of Neurology. Published continuously since 1951, it is now a weekly with 48 issues per year. Copyright (O 2018 American Academy of Neurology. All rights reserved. Print ISSN: 0028-3878. Online ISSN: 1526-632X.

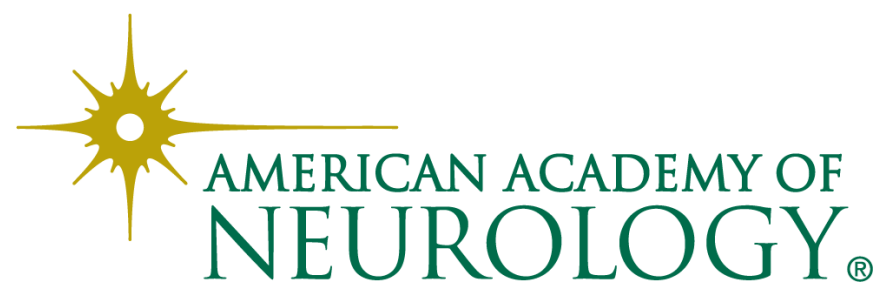

